\title{
BIOMATERIALS PROCESSING BY RP TECHNOLOGIES (RAPID PROTOTYPING) USED IN THE IMPLANTS MANUFACTURING
}

\author{
BAILA, D[iana]
}

\begin{abstract}
Biomaterials used to selective laser sintering process are made by powders of stainless steel, titanium powders and composite powders titan-hydroxyapathite.

The titan alloy TA6V is used frequently in ortopaedic prothesis because presents a good resistance to corrosion due to the titanium oxide layer on the surface of the metal who prevents the achievement of reactions between titanium and surrounding environment and it's not toxic for human body.

The hydroxyapathite contains collagen like the structure of bone and can be more easy to integrate the implantsto human body.

Keywords: biomaterial, computerized tomography, selective laser sintering, hydroxyapathite
\end{abstract}

\section{INTRODUCTION}

The process of rapid prototyping by selective laser sintering based on the materialisation of a product CAD by adding successive layers. Under this method, the laser will cover point by point the entire aria of section, sintering the fine layer of material deposited on the platform. It is not necessary to build supports because the material previously (sintered or not) constitutes support for the current layer of the material.

The materials used in the process of selective laser sintering are particularly diverse, since all of polyamides (DuraForm PA, PA1500, PA3200GF, PA1300GF, PA2200), metallic powders (DirectMetal-VI, VI, DirectMetal 100-RapidSteel 1.0 RapidSteel 2.0), powders on the basis of quartz or zirconium (EOSINT S quartz, zircon EOSINT HT), titanium TA6V powders, particulate composite powders titanium-hydroxyapathite.

\section{SELECTIVE LASER SINTERING PROCESS}

Selective laser sintering is a manufacturing process in a free form of components by powder sintering. Rapid prototyping technologies help to identify the potential problems that may arise in the process of design and conception. With a prototype can be seen real if two areas merge correctly or if the merge points line up well.

The rapid prototyping manufacturing Sinterstation 2000 DTM (SLS) (fig.1) made prototypes of both beneficiaries of the industry, but also in the medical domain-implants aid in case of accidents, especially skulls using a computerized tomography and a CAD system. [2],[4],[5]

In manufacturing process of rapid prototyping, the nitrogen is an important element to maintain an inert atmosphere in the sintering room and to prevent the emergence of large quantities of dust explosions in various materials (plastics, polystyrene, metal and ceramics). [2],[4],[5]

Fig. 1. Manufacturing SLS system SINTERSTATION 2000

Biomaterials processing by selective laser sintering are used in the manufacture of medical implants: dental implants, orthopaedic hip implants, knee implants, implants of the elbow joint of the shoulder joint implants.

\section{BIOMATERIALS PROCESSING BY SELECTIVE LASER SINTERING}

\subsection{Powders of stainless steels}

Stainless steels are the most ancient biomaterials used for medical implants. In figure 2 is presented the structure of stainless steels powders $316 \mathrm{~L}$ used on manufacturing SLS system realized by scanning electron microscope. [3]

In the case of powder particle form 304L (fig.2), and other characteristics of the powder are controlled to produce a powder who presents an apparent density 2.5 -

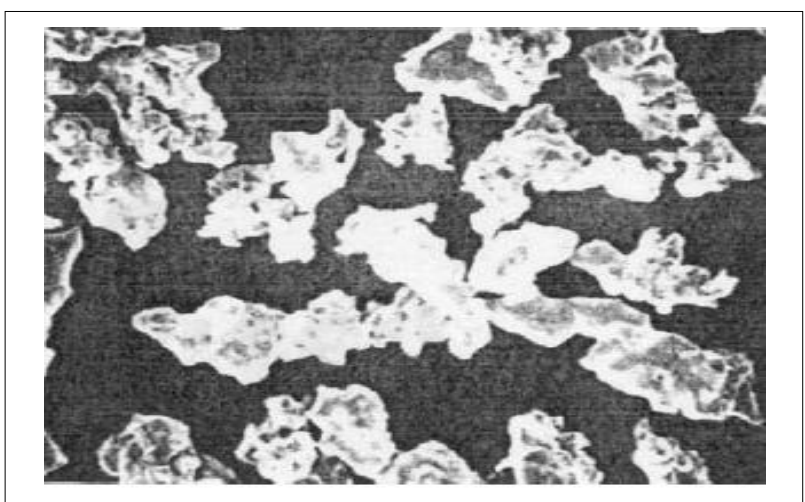


Fig. 2. Powder of stainless steels 304L (SEM) (x100)

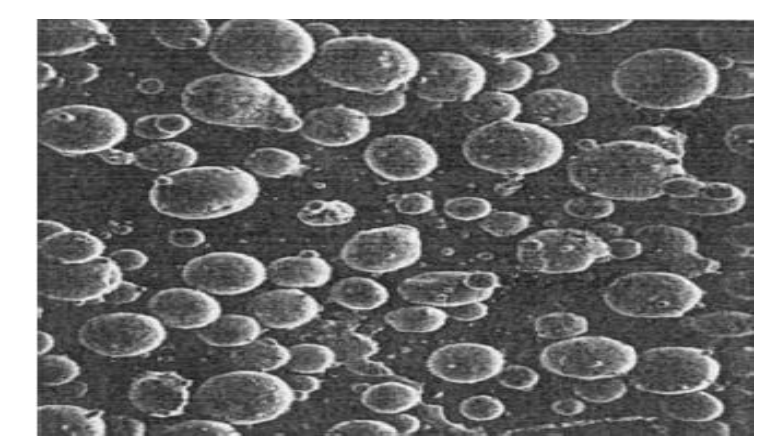

Fig. 3. Powder of stainless steels 316L (SEM) (x100)

$3.2 \mathrm{~g} / \mathrm{cm}^{3}$, with good resistance to compact green. [3]

The atomization with gas (nitrogen or argon) of the stainless steels powders, for example of steel $316 \mathrm{~L}$, will lead to the formation of particles with spherical form as in figure 3. [6]

The green compacts of stainless steel $316 \mathrm{~L}$ have an apprent density more that $5 \mathrm{~g} / \mathrm{m}^{3}$ and an excellent mechanical stability.

Stainless steel presents a high mechanical resistance, a good corrosion resistance, a low toxicity, degree of cleaning up identical to that of glass, good biocompatibility.

Chemical composition of austenitic steels is similar to conventional ones like in table 1 .

\begin{tabular}{|c|c|c|c|c|c|c|c|}
\hline \multirow{2}{*}{ alloy } & \multicolumn{3}{|c|}{ Composition \% } & \multicolumn{2}{|c|}{$\begin{array}{c}\text { Granulometric } \\
\text { analysis }\end{array}$} & \multirow{2}{*}{$\begin{array}{c}\text { Aparent } \\
\text { density } \\
\text { g/cm }\end{array}$} & \multirow{2}{*}{$\begin{array}{c}\text { Fluidity } \\
\text { s/50g }\end{array}$} \\
\hline & $\mathrm{Cr}$ & $\mathrm{Ni} \mathrm{Si}$ & Mo & $\begin{array}{l}+100 \\
>150\end{array}$ & $\begin{array}{r}-325 \\
<44 \mu \mathrm{m}\end{array}$ & & \\
\hline $\begin{array}{l}\text { Auste } \\
\text { nitic } \\
304 \mathrm{~L}\end{array}$ & 18 & 110.8 & - & $1-4$ & $30-45$ & $2.5-2.8$ & $28-32$ \\
\hline $\begin{array}{l}\text { Auste } \\
\text { nitic } \\
316 \mathrm{~L} \\
\end{array}$ & 18 & 130.75 & 3 & $1-4$ & $35-45$ & $2.6-3$ & $24-32$ \\
\hline
\end{tabular}

Tab. 1. Chemical composition of austenitic stainless steels

Mechanical properties of type 316L steel and 304L are given in table 2 .

\begin{tabular}{|l|c|c|c|c|}
\hline alloy & $\begin{array}{c}\text { Young's } \\
\text { modulus } \\
\text { E[GPa] }\end{array}$ & $\begin{array}{c}\text { Yield strength } \\
\text { Rco[MPa] }\end{array}$ & $\begin{array}{c}\text { Traction } \\
\text { resistance } \\
\text { Rm [GPa] }\end{array}$ & $\begin{array}{c}\text { Corrosion } \\
\text { resistance (to } \\
\mathbf{I 0}^{-7} \text { cycles } \\
\boldsymbol{R}=1 \text { MPa) }\end{array}$ \\
\hline $\begin{array}{l}\text { Auste } \\
\text { nitic } \\
\text { 304L }\end{array}$ & $190-210$ & 320 & 420 & $220-250$ \\
\hline $\begin{array}{l}\text { Auste } \\
\text { nitic } \\
\text { 316L }\end{array}$ & 193 & 331 & 454 & $241-276$ \\
\hline
\end{tabular}

Tab. 2. Mechanical properties of austenitic stainless steels

But as all materials present the phenomenon of ageing and requires changing the implant after several years. Stainless steels are used for orthopedic implants, medical equipment.

\subsection{Powders of alloy Ti-6\% Al-4\% V}

TA6V powders of titanium (Ti-6\% Al-4\% V) are widely used in various fields of industry of mechanical engineering, naval and aerospace industry, in the manufacture of medical products and medical instrumentation. Titanium alloy powders can be obtain by two process:

- process hydride-melting-dehydride of titanium alloy; - atomisation process of titanium alloy.

Titanium hydride $\left(\mathrm{TiH}_{2}\right)$ is a chemical compound of titanium and hydrogen, a hydride. It is highly reactive and needs to be kept away from heat and strong oxidizers.

In figure 4 are presented a sponge of rutile. In figure 5 are presented a X-ray diffractogram corresponding to $\mathrm{TiH}_{2}$ powder in $\alpha$-phase after dehydriding process.

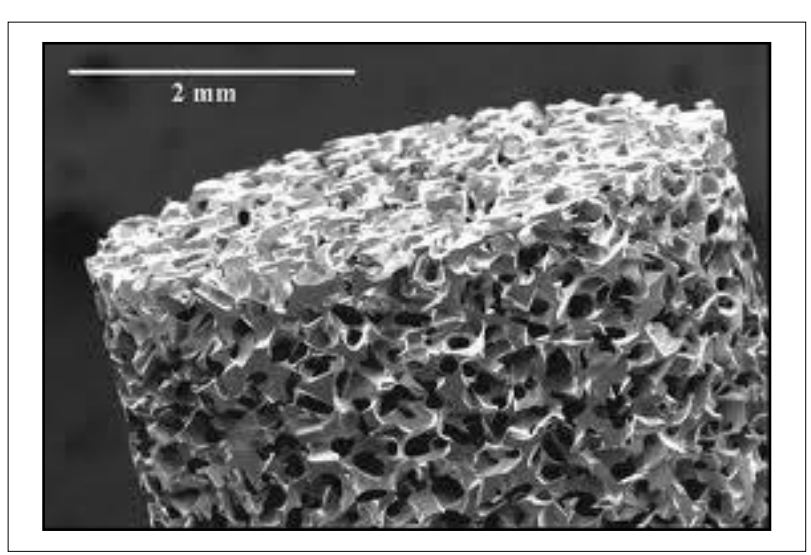

Fig. 4. Image of rutile sponge

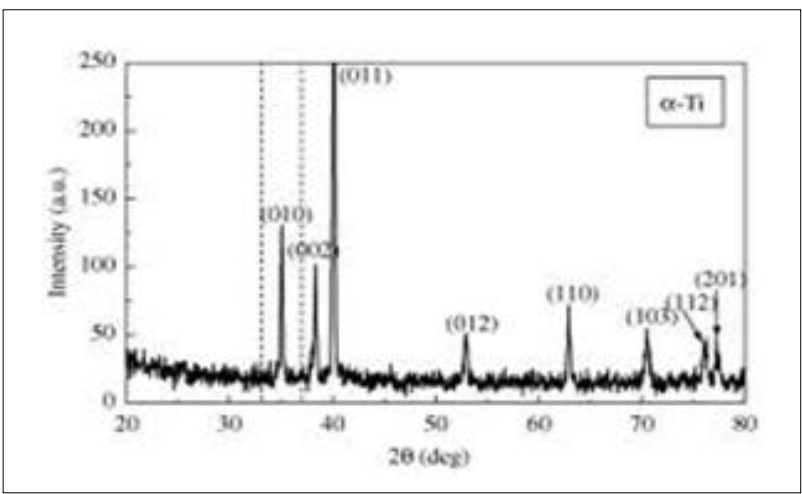

Fig. 5. Diffractogram of $\mathrm{TiH}_{2}$ powder in $\alpha$-phase after dehydriding process

In table 3 is presented titanium hydride typical physical constants. [1]

\begin{tabular}{|l|l|}
\hline Physical constants & Value \\
\hline Molecular Weight (g/mol.) & 49.92 \\
\hline Density $(\mathrm{g} / \mathrm{cm} 3)$ & $\sim 3.76$ \\
\hline Sensitivity & moisture sensitive \\
\hline Melting Point $\left({ }^{\circ} \mathrm{C}\right)$ & 400 \\
\hline Boiling Point $\left({ }^{\circ} \mathrm{C}\right)$ & 3262 \\
\hline Auto Ignition Temp. $\left({ }^{\circ} \mathrm{C}\right)$ & 342 \\
\hline Crystal Structure & fluorite $($ cubic $)$ \\
\hline Merck & 14,9473 \\
\hline Odour & odorless \\
\hline Solubility In Water & insoluble \\
\hline Color & grey \\
\hline
\end{tabular}

Tab. 3. Titanium hydride typical physical constants 
In figure 6 is presented the powder of titanium alloy Ti-6\%Al-4\% V obtain by hydride-melting-dehydride process. The technology to obtain the titanium powder by process of hydride-melting-dehydride is based on particular behavior of titanium in presence of hydrogen.

The solvus curve in the diagram is highly inclined and ensures diffusion of large quantities of hydrogen in solid solution.

Heating in terms of balance, for temperatures above $450^{\circ} \mathrm{C}$, hydrogen form a hydride metastable $\mathrm{TiH}_{2}$. This hydride may be brought to the ambiance temperature in the atmosphere without to decomposing or complexing by reaction. [1]

This hydride is very brittle and can be easy, melting, thus obtaining a large distribution of granulometric fractions. In case of heating in a vacuum, the hydride decomposes, releasing hydrogen.

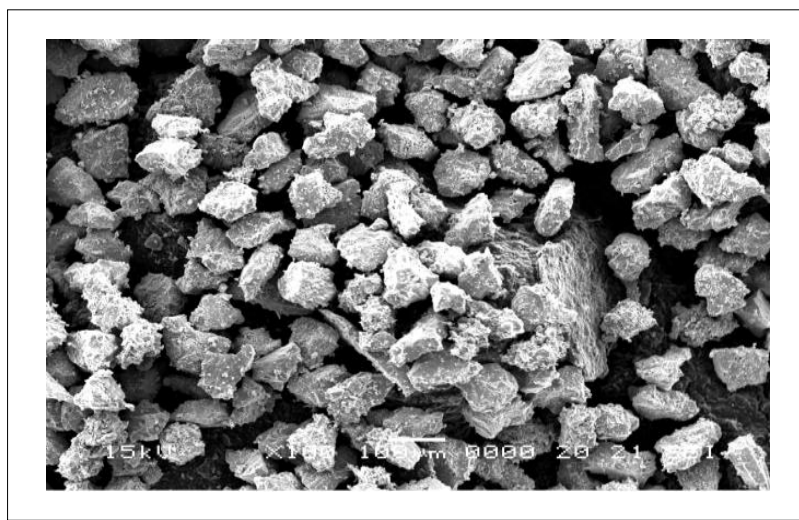

Fig. 6.Powder of titanium alloy Ti-6\% Al-4\%V obtain by hydridemelting-dehydride process (SEM) (x100)

In figure 7 is presented the EDX analysis on the titanium alloy Ti-6\% Al-45V obtain by hydride-meltingdehydride process and remarck the great purity of powder. [1]

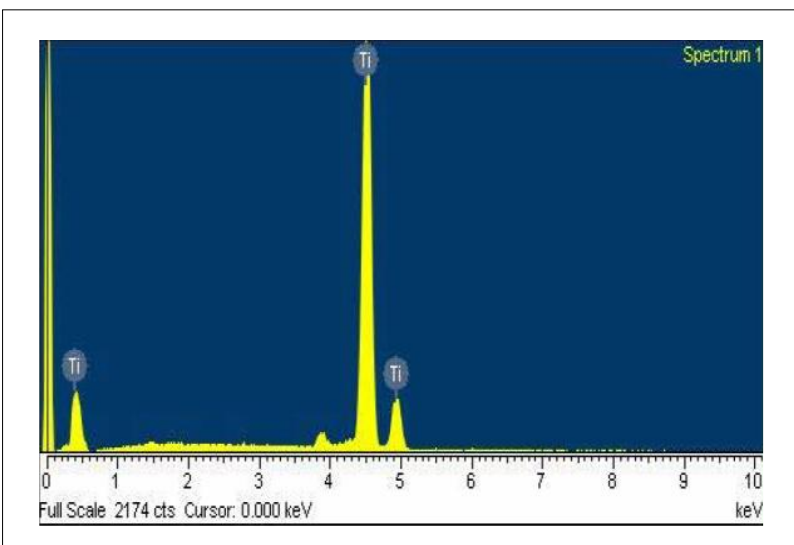

Fig. 7. EDX analysis of titanium alloy Ti-6\%Al-4\%V obtain by hydride-melting-dehydride process

In figure 8 is presented the powder of titanium alloy who is obtain by atomisation process.

In figure 9 is presented the EDX analysis on the titanium alloy Ti-6\% Al-45V obtain by atomisation process and remarck the great purity of powder and a faible presence of stibium.
The powder of titanium TA6V obtain by hydridemelting-dehydride process presents a better purity of powder that the powder obtains by atomisation process.

The atomisation process is more expansiv that the hydride-melting-dehydride process. [1]

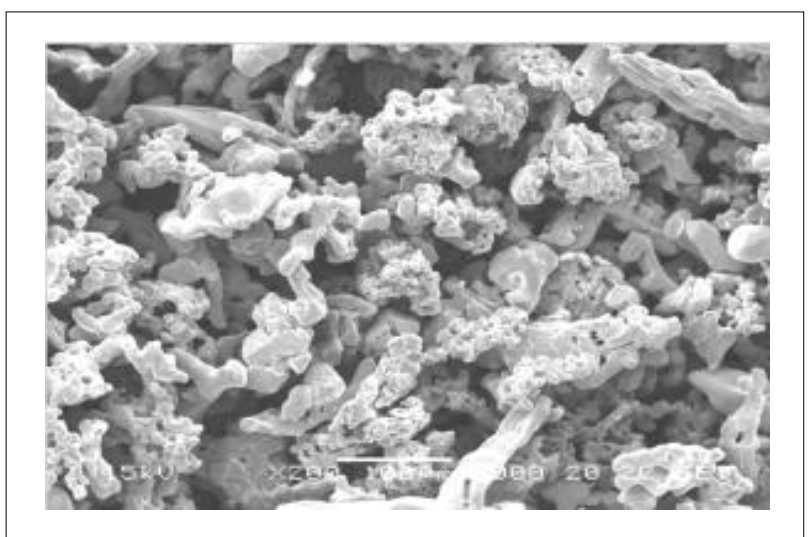

Fig. 8. Powder of titanium alloy Ti-6\%Al-4\%V obtain by atomisation process (SEM) (x200)

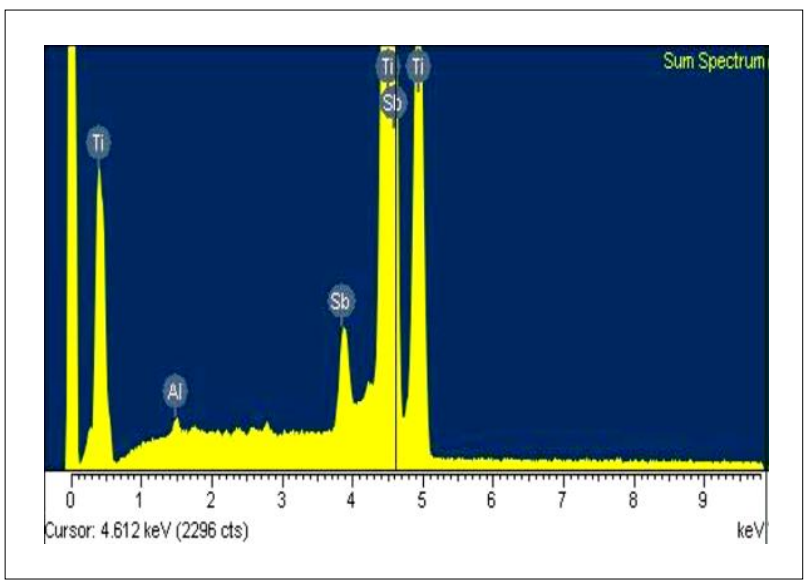

Fig. 9.EDX analysis of titanium alloy Ti-6\%Al-4\% obtain by atomisation process

Titanium alloy TA6V present a high mechanical resistance, very good corrosion resistance, low chemical toxicity reactivity, high degree of biocompatibility cleanup identicaly like the glass, high adherence of the implant like in table 4.

\begin{tabular}{|c|c|c|c|}
\hline \multirow{2}{*}{ alloy } & Composition \% & \multirow{2}{*}{$\begin{array}{c}\text { Young's modulus } \\
\text { E[GPa] }\end{array}$} & \multirow{2}{*}{$\begin{array}{c}\text { Traction } \\
\text { resistance } \\
\operatorname{Rm}[\mathrm{MPa}]\end{array}$} \\
\hline & $\mathrm{Al} \quad \mathrm{V} \quad \mathrm{Fe} \quad \mathrm{Ti}$ & & \\
\hline TA6V & $\begin{array}{llll}6 & 4 & 0.25 & \text { rem }\end{array}$ & $\begin{array}{ll}0 \% \text { porosity - } & 124 \\
40 \% \text { porosity- } & 270\end{array}$ & $\begin{array}{l}294 \\
240\end{array}$ \\
\hline
\end{tabular}

Tab. 4. Mechanical properties of alloy TA6V [1]

Titanium alloy powders can be obtain either by atomisation, either by melting.

In the process of atomisation the powder will present a free spherical form grains.

In the process of melting the powder will present irregulate free-form granulation with sharp peaks which present the advantage for selective laser sintering processing, because can realize metallic bonding between two grains more easily. [1] 


\subsection{Composite powders titan-hydroxyapathite}

The chemical formula of hydroxyapatite is $\mathrm{Ca}_{10}\left(\mathrm{PO}_{4}\right)_{6}(\mathrm{OH})_{2}$. It is an inorganic compound containing collagen and has a structure similar to human bone tissues.

The selective laser sintering station can use the hydroxyapathite powders to obtain the prothesis in orthopedy, the hip prothesis, the knee prosthesis.

The collagen contributes to hierarchical structure of bone. The collagen and the hydroxyapathite are arranged to form the compound to molecular level.

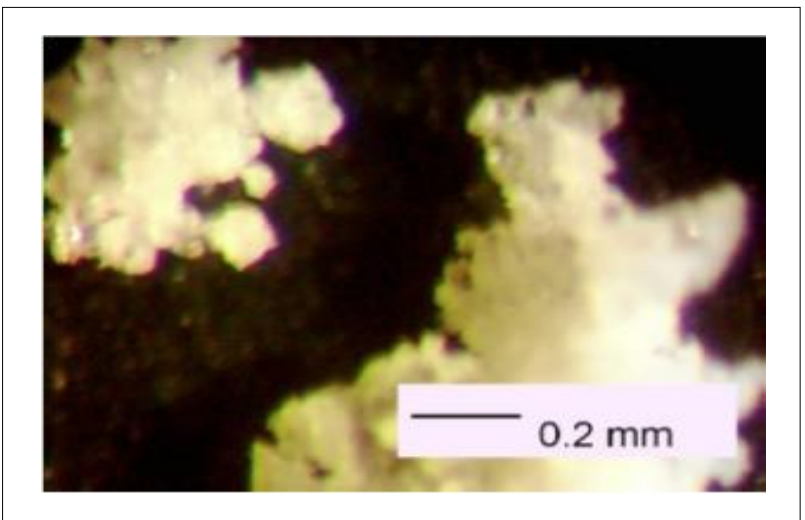

Fig. 10. SEM image of a particle of hydroxyapathite (x200)

The arrangement can be compromise in same cases and because of the alteration structure of collagen in the same diseases of bones and which conduct to physical properties very affects.

Mechanical resistance is low, biocompatibility is increased and the adhesion of the implant to bone is done quickly. In figure 10 is presented a SEM image of a particle of hydroxyapathite.

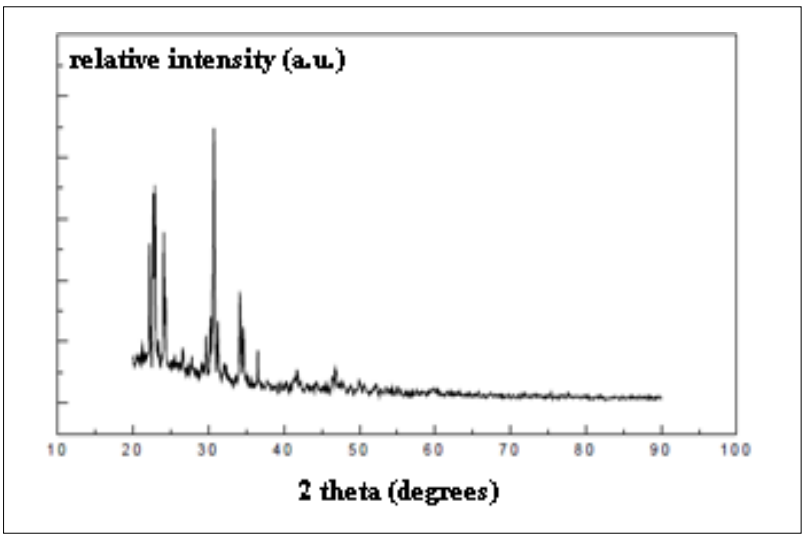

Fig. 11. Diffractogram of hydroxyapathite

In figure 11 is presented the diffractogram spectrum of hydroxyapathite powder. Hydroxyapathite is a revolutionary material used in the production of implants but like composite form together with titanium alloy.

The prothesis U.T.A.H. is based on a modular concept, the cone being available in various lengths and angles.

Crafted from a primary structure of titanium alloy (TA6V ELI), the rod U.T.A. is covered in full with hydroxyapatite.

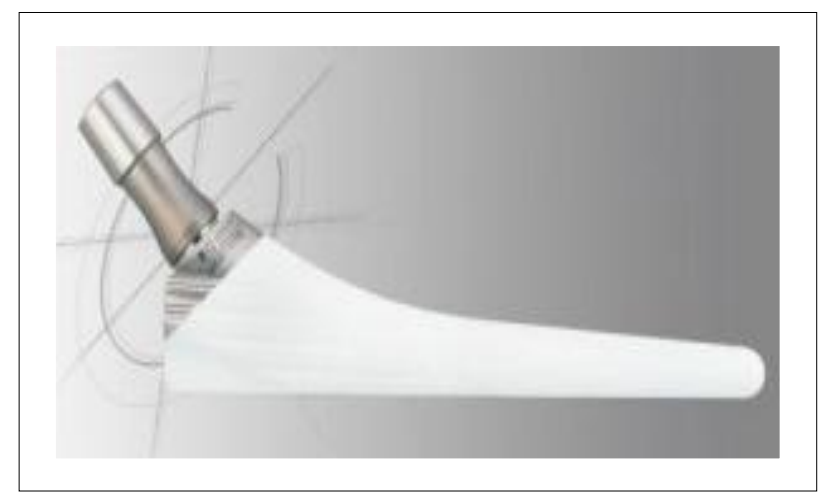

Fig. 12. Ortopaedic implants hip-joint prothesis U.T.A.H. [7]

\section{CONCLUSION}

A material who accomplishes in the beginning all the requirements of compatibility can lose in time these qualities not only because of the processes of degradation, fatigue, wear, and because the surrounding, healthy tissues, initialy or just plain sick and ageing.

The most revolutionary material is the composite titane-hydroxyapathite who present very good adherence to bone, because of collagen contain in hydroxyapathite. The prothesis realized from this composite Ti-HA is not toxic for human body and the risk of implant rejection is very low.

\section{REFERENCES}

[1] Baila, D. (2009). Cercetari teoretice si experimentale privind asimilarea de noi materiale biocompatibile prelucrabile prin tehnologiile RP (Rapid Prototyping), Ph.D. Dissertation, Department T.C.M., Tehnical University, Cluj-Napoca, Romania

[2] Berce, P. \& a. (2000), Fabricarea rapida a prototipurilor, Editura Tehnica, ISBN, Bucarest

[3] Ratner B and athers (1996), Biomaterials Science - An introduction to materials in medicine, Academic Press

[4] Chua, CK. Leong, KF (1997), Rapid Prototyping:Principles and aplications in manufacturing, ISBN, John Wiley, New York

[5] Dickens, PM. (1995), Research developements in rapid prototyping, Proceedings of Engineering Manufacture, ISBN, Nottingham, Great Britain, pp.261-266

[6] Werner S., (1997), Powder Metallurg - Processing and materials EPMA

[7] www.romedic.ro/proteza-de-sold-necimentatautah0H2435 Accessed on: 2012-09-10 